\title{
The three pillars of bilingual physical education
}

\author{
Os três pilares da educação física bilíngue
}

\section{Los tres pilares de la educación física bilingüe}

\author{
Antonio Muller ${ }^{1}$ iD , Cesar Conceição Rodrigues Júnior ${ }^{1}$ iD \\ ${ }^{1}$ Regional University of Blumenau, Blumenau, Santa Catarina, Brazil. \\ Corresponding author: \\ Antonio Muller \\ Email: antoniomuller2@hotmail.com
}

How to cite: Muller, A., \& Rodrigues Júnior, C. C. (2021). The three pillars of bilingual physical education. Revista Tempos e Espaços em Educação, 14(33), e16230. http://dx.doi.org/10.20952/revtee.v14i33.16230

\begin{abstract}
This article is a literature review with the objective of characterizing bilingual physical education, to then present and discuss the biggest challenge of the discipline, which is to keep the balance between the objectives and demands of physical education along with the process of acquiring a new language, and then create concepts for how to achieve this balance. This balance proposed for the discipline is something complex and at the same time subtle, we analyzed a specific article that seeks to concentrate all the difficulties of bilingual physical education in two dilemmas, and based on this analysis, the concept of the "three pillars of bilingual physical education" is proposed. The concept of the three pillars represents, in an integral and objective way, all the demands that the teacher needs to take into consideration to teach an ideal bilingual physical education class. The first pillar represents physical education, and all its demands. The second pillar is the process of acquiring a new language. Finally, the third pillar represents the optimization of time that the teacher needs to make to adapt the new demands within the classes, where with these pillars the most common mistakes that happen in the search for an efficient bilingual physical education were presented. It was concluded that to achieve an efficient bilingual physical education there is a need to balance the objectives of physical education mixed with the acquisition process of a new language, through the concept of the three pillars.
\end{abstract}

Keywords: Bilingual education. Bilingual physical education. Physical education.

\section{RESUMO}

Esse artigo é uma revisão bibliográfica com objetivo de caracterizar a educação física bilíngue, para em seguida apresentar e discutir o maior desafio da disciplina que é manter o equilíbrio dos objetivos e demandas da educação física junto com o processo de aquisição de uma nova língua, e após isso criar conceitos para como alcançar tal equilíbrio. Este equilíbrio proposto para a disciplina é algo complexo e ao mesmo tempo sutil, foi analisado um artigo específico que busca concentrar 
todas as dificuldades da educação física bilíngue em dois dilemas, e com base nesta análise é proposto o conceito dos "três pilares da educação física bilíngue". O conceito dos três pilares representa de forma integral e objetiva todas as demandas que professor precisa levar em consideração para ministrar uma aula de educação física bilíngue ideal. O primeiro pilar representa a educação física, e todas as suas demandas. O segundo pilar consiste no processo de aquisição de uma nova língua. Por fim o terceiro pilar representa a otimização de tempo, que o professor necessita fazer para adequar as novas demandas dentro das aulas, onde com esses pilares foi apresentado erros mais comuns que acontecem na busca da educação física bilíngue eficiente. Foi concluído que para se obter uma educação física bilíngue eficiente existe a necessidade do equilíbrio dos objetivos da educação física mesclados com a aquisição do processo de uma nova língua, por meio do conceito dos três pilares.

Palavras-chave: Educação física bilíngue. Educação física. Ensino bilíngue.

\section{RESUMEN}

Este artículo es una revisión de la literatura con el objetivo de caracterizar la educación física bilingüe, para luego presentar y discutir el mayor desafío de la disciplina, que es mantener el equilibrio de los objetivos y demandas de la educación física junto con el proceso de adquisición de un nuevo idioma, y luego crear conceptos sobre cómo lograr ese equilibrio. Este equilibrio propuesto para la disciplina es complejo y a la vez sutil, se analizó un artículo específico que busca concentrar todas las dificultades de la educación física bilingüe en dos dilemas, y en base an este análisis, el concepto de los "tres pilares de la educación física". Se propone la educación" Bilingüe". El concepto de los tres pilares representa, de forma integral y objetiva, todas las exigencias que un docente debe tener en cuenta para impartir una clase de educación física bilingüe ideal. El primer pilar representa la educación física y todas sus demandas. El segundo pilar es el proceso de adquisición de un nuevo idioma. Finalmente, el tercer pilar representa la optimización del tiempo, que el docente debe hacer para adaptarse a las nuevas demandas dentro de las clases, donde con estos pilares se presentaron los errores más comunes que ocurren en la búsqueda de una educación física bilingüe eficiente. Se concluyó que, para obtener una educación física bilingüe eficiente, es necesario equilibrar los objetivos de la educación física mezclados con la adquisición del proceso de un nuevo idioma, a través del concepto de los tres pilares.

Palabras clave: Educación bilingüe. Educación física bilingüe. Educación física.

\section{INTRODUCTION}

It's necessary to initially define what type of bilingual education we are going to address, since bilingual education can address several topics, such as bilingual education for the deaf-mute, bilingual education for indigenous peoples, among others.

However, in this publication, bilingual education will be addressed within the perspective of acquiring a new language incorporated within the mandatory requirements of a bilingual curriculum.

In this modality, the student attends school full time, and the acquisition of a new language occurs through a greater focus on learning this new pre-selected language ${ }^{1}$. This focus happens with a greater number of classes focused on learning a new language, in addition to classes of other subjects taught in the selected language.

\footnotetext{
${ }^{1}$ This focus happens with a greater number of classes focused on learning a new language, in addition to classes of other subjects taught in the selected language. In a school focused on learning English, for example, students would have a larger class load of English, and other subjects would also be taught in English, immersing students in the language.
} 
In a school focused on learning English, for example, students would have a larger class load of English, and would have other subjects that would also be taught in English, immersing students in the language.

There are already bilingual schools in the public system in Brazil, but at the time of writing of this article, their vacancies were extremely limited. As for private schools, there is an increasing demand for such schools. In São Paulo, for example, the number of students grew, between 2014 and 2019 , from 2,800 to 4,600 , however, the tuition fees for such schools limits the entry of most of the brazilian population (Vieira, 2019).

The definition of bilingual individual that will be used is brought by Grosjean (1997) as someone who uses two or more languages on a regular basis in their everyday life. Grosjean (1997) continues that these bilingual individuals are rarely fluent in all their languages (many cannot read or write in one of their languages), many have accents, and few are proficient translators or interpreters.

Regarding physical education, in Brazil, it is defined by BNCC having three key elements, body movement, internal organization and cultural product (Brasil, 2018). Thus, physical education is a discipline with a wide range of approaches, Brasil (2018) continues that the variability of possibilities enriches the student's experience, allowing them to have access to a huge cultural universe:

It is essential to emphasize that Physical Education offers a number of possibilities to enrich the experience of children, young people and adults in Basic Education, allowing access to a vast cultural universe. This universe includes body knowledge, aesthetic, emotional, ludic and agonistic experiences, which are part of, but not restricted to, the typical rationality of scientific knowledge that usually guides pedagogical practices at school. Experimenting and analyzing the different forms of expression that are not based only on this rationality is one of the potentialities of this component in Basic Education. Beyond the experience, the effective experience of body practices gives students the opportunity to participate autonomously in contexts of leisure and health (Brasil, 2018, p. 213). ${ }^{2}$

Finally, it is possible to build a definition of bilingual physical education, where it is characterized by the junction of all the demands, goals, and activities of physical education (in Brazil defined in BNCC), with the process of acquiring a new language. Since bilingual physical education should always work together with other subjects to assist in the process of acquiring this new language, comprehension and orality are aspects present almost daily in class, but reading and writing are aspects, for example, not so present in class. However, the question is, what are the differences present in the bilingual physical education class that makes it different from the regular physical education class?

\section{PARTICULARITIES OF BILINGUAL PHYSICAL EDUCATION}

There is a tendency to simplify the subject of bilingual physical education, where many will simply say that it is enough to teach a physical education class in another language. With this oversimplification, bilingual physical education teachers will get stuck in many situations where such a narrow definition will not encompass the many daily difficulties of the classes, leaving teachers at the mercy of unfair criticism and/or misdirection in the face of any problem/doubt.

Ramos \& Omenaca (2011) present physical education as a unique place for learning a new language:

\footnotetext{
${ }^{2}$ É fundamental frisar que a Educação Física oferece uma série de possibilidades para enriquecer a experiência das crianças, jovens e adultos na Educação Básica, permitindo o acesso a um vasto universo cultural. Esse universo compreende saberes corporais, experiências estéticas, emotivas, lúdicas e agonistas, que se inscrevem, mas não se restringem, à racionalidade típica dos saberes científicos que, comumente, orienta as práticas pedagógicas na escola.
} 
Note that the vocation of Physical Education places it in a place where different aspects of reality linked to the current culture converge, so the knowledge of these elements can be progressively addressed in English, either exclusively within the area or in interdisciplinary projects with other areas of the curriculum, which opens an especially fertile field for the continuous use of English in a wide variety of oral or written experiences with older students or students with proficiency in the language (Ramos \& Omenaca, 2011, p. 158-159, our translation). ${ }^{3}$

Chiva-Bartoll et al. (2015), Griva et al. (2010) and Garcia et al. (2016) argue that physical activity along with learning another language fosters the development of communication skills.

However, Ramos \& Omenaca (2011) warn that such perspectives and possibilities that bilingual physical education classes may have, should never abandon the directions, demands and activities of physical education. That is, bilingual physical education cannot be emancipated from physical education.

The concern with integrating the bilingual aspect within physical education is well illustrated in Salvador-García et al. (2017) who conducted a systematic review on the most addressed topics in publications related to bilingual physical education, with the main theme being how to adapt the process of acquiring a new language within physical education classes.

Salvador-García et al. (2017) present the existence of a divergence in the different investigations (objectives, methodology, types of intervention, etc.) within bilingual physical education research, however, they all convert to the same theme, physical activity, and language learning.

In this integration process, a particularity of the discipline emerges, with the insertion of linguistic objectives within physical education classes, there is a decrease in motor activity time.

Coral et al. (2017) point out that there is a loss in students' activity time due to the very difficulties inherent to the practice, mostly due to the need to balance physical activities with language demands.

Hita \& Canto (2017) have a similar conclusion where they cite the loss in activity time, and they point out that the planning and execution of bilingual physical education classes are much more complex than regular physical education classes.

The subject of physical education, within a bilingual context, is not merely teaching the same class in another language, several nuances must be considered, such as, for example, what to do if the student does not understand something or everything that is being presented during the classes? The lay solution is simple, just translate it, correct? But how to use this translation? When should I do the translation? Can I translate the whole class all the time? Is it beneficial to translate the entire class? The problem of translating is already something complex in language classes, within bilingual physical education it is something even more complex, which cannot have a simplistic approach.

\section{TRANSLATION IN BILINGUAL PHYSICAL EDUCATION CLASSES}

The use of translation is a complex and old topic within the literature. In the early 20th century onward, many methodologies and publications stated that teaching a second language should be done without using the student's first language, making popular the idea that translating something into the first language hinders the process of second language acquisition (Liao, 2006).

\footnotetext{
${ }^{3}$ Notar que la vocación de la Educación Física la ubica en un lugar en el que confluyen diferentes aspectos de la realidad ligados a la cultura actual. El conocimiento de estos elementos puede abordarse así de forma progresiva en inglés, bien exclusivamente dentro del área, bien en proyectos interdisciplinares con otras áreas del currículo, lo que abre un campo especialmente fértil para el uso continuado del inglés en una gran variedad de experiencias orales o escritas con alumnos de más edad o dominio del idioma.
} 
Within the Brazilian context, Camargo (2012) conducted a survey with foreign language teachers about translation into mother tongue within English language classes. Of which nine teachers who participated in the study, only one said he felt comfortable using the first language (Portuguese) during classes, but at specific times, such as to maintain discipline and/or control. The other teachers defended not using translations or the first language during the classes.

Camargo (2012), at the end of the article, in his conclusions mentions that there is a negligence in the debate of whether to use translation and mother tongue:

The theme brought for discussion, the presence of translation (and also of the mother tongue) in the foreign language classroom is often neglected, although its problematization is essential for us to break the inertia of thoughts that have been plastered for so many years, which ignore the subjectivity of the student and want, at all costs, to maintain a proposal for language teaching as an objective process, massive and equal for all (Camargo, 2012 p. 105, our translation). ${ }^{4}$

Macaro (2001) cites that translation can assist in the process of second language acquisition, the first language during class is a phenomenon that cannot be dissociated from its sociocultural environment, and by research it is necessary to create parameters for first language use and translation.

Spahiu (2013) cites that there is no solid data base to justify the total exclusion of first language from classes, such exclusion may even demotivate and hinder performance.

González (2017) has a similar conclusion, where the total exclusion of the first language in the process of acquiring a new language is counter productive.

Vermes (2010) in the same vein, concludes that there are good reasons to include translation in the pedagogical environment, and its non-use are based on a limited view of translation itself.

Sharma (2006) also agrees that a total ban on the use of the first language is something that is counter productive, however, Sharma (2006) is against excessive or frequent use of the first language, the teacher should be careful with group work and whenever possible discourage the use of the native language.

Macaro (2001) warns that we need to present teachers, especially for those less experienced, with a framework where it is possible to differentiate between using the first language as a valid and useful tool and using the first language because it is the easy option. Solutions and methods must be constantly questioned; however, these solutions are never without question. (Stibbard, 1994).

García-Calvo (2019) exposes that in bilingual physical education classes, it is advisable to use the first language to clarify doubts of students about specific topics, contexts, or activities. GarcíaCalvo (2019) continues that the teacher needs this flexibility in the use of the first language, especially for younger students, and he concludes that it is necessary to create parameters so that students are not dependent on translations or the first language during bilingual physical education classes.

Coral (2012) cites that it is essential that the bilingual physical education classes, there is a balance between motor, cognitive and linguistic demands. Coral (2012) continues that the most fruitful activities have, in a balanced way, language and movement, without slowing down the pace of activities. Such balance may seem abstract, but what are the dilemmas that the bilingual physical education teacher faces to reach this supposed balance of objectives?

\footnotetext{
${ }^{4} \mathrm{O}$ tema trazido para discussão, a presença da tradução (e também da língua materna) na aula de língua estrangeira é, muitas vezes, negligenciado, embora sua problematização seja imprescindível para quebrarmos a inércia de pensamentos há tantos anos engessados, que ignoram a subjetividade do aluno e querem, a todo custo, manter uma proposta de ensino de línguas como um processo objetivo, massificador, igual para todos.
} 


\section{THE DILEMMAS OF BILINGUAL PHYSICAL EDUCATION}

Coral \& Lleixà (2014) presented after an action research, what would be the dilemmas that bilingual physical education teachers face in their daily lives. This article by Coral and Lleixà (2014) was specifically chosen among many others because it has as coauthor Dr. Josep Coral-Mateu, who, at the time of writing this publication, is a professor at the Universitat Autònoma de Barcelona, has several general publications within physical education, and since 2007 has led the PE-in-CLIL project, a project to implement bilingual physical education within the CLIL methodology (which will be discussed in the next section). In addition, he has several publications on the topic of bilingual physical education, many of them published in renowned journals such as the International Journal of Bilingual Education and Bilingualism, and his work is widely cited. At the time of writing this article, according to Google Scholar, his publications have been cited more than 297 times. His years of experience in the field of bilingual physical education bring a unique experience that is also present in this publication.

Coral \& Lleixà (2014) present these dilemmas of bilingual physical education within the CLIL methodology. Given that CLIL is the acronym for Content and language integrated learning, it is a bilingual methodology in which a subject is taught using another language rather than the students' first language (British Council, 2020), which will be presented below for better contextualization.

\section{CLIL physical education}

According to Coyle et al. (2010), CLIL is flexible and can have several models that cover different contexts, for example:

Subject topic/syllabus adapted for to explore the subject from a different perspective whilst improving foreign language skills i.e., teaching in the target language to explore the subject from different perspectives whilst developing specific foreign language skills. Example: Human Geography through the medium of French (study of Senegal); Cross curricular project which involves subject teachers planning together. An example might be a study on different aspects of eco-citizenship or the global village, fair trade or war \& peace. (Coyle et al., 2010, p. 2).

Coyle et al. (2010, p. 4) present four basic principles that CLIL can be built upon:

Content- At the heart of the learning process lie successful content or thematic learning and the acquisition of knowledge, skills and understanding. Content is the subject or the project theme. Communication- Language is a conduit for communication and for learning. The formula learning to use language and using language to learn is applicable here. Communication goes beyond the grammar system. It involves learners in language using in a way which is different from language learning lessons (of course CLIL does involve learners in learning language too but in a different way).; Cognition for CLIL to be effective, it must challenge learners to think and review and engage in higher order thinking skills. CLIL is not about the transfer of knowledge from an expert to a novice. CLIL is about allowing individuals to construct their own understanding and be challenged - whatever their age or ability. A useful taxonomy to use as a guide for thinking skills is that of Bloom. He has created two categories of thinking skills: lower order and higher order. Take Bloom's taxonomy for a well-defined range of thinking skills. It serves as an excellent checklist. Culture For our pluricultural and plurilingual world to be celebrated and its potential realised, this demands tolerance and understanding. Studying through a foreign language is fundamental to fostering international understanding. 'Otherness' is a vital concept and holds the key for discovering self. Culture can have wide interpretation e.g., through pluricultural citizenship. 
Coyle et al. (2010) cite that there is no set model for CLIL, however, all models have one principle in common, that in some way subject content and language learning are integrated.

Coral \& Lleixà (2014) define CLIL as teaching curriculum content through a foreign language. Thus, physical education, within the CLIL perspective, can be considered a bilingual physical education. With this contextualization of what CLIL education is, we will continue with the analysis of Coral \& Lleixà's (2014) article, which presents two dilemmas that teachers need to solve.

\section{Dilemma 1: attractive versus effective activities}

The authors define attractive tasks as those with a greater focus on physical education and effective tasks as tasks related to linguistic goals.

Since Coral \& Lleixà (2014) discuss that if attractive activities are prioritized, linguistic goals are affected, and if effective activities are prioritized, motor goals are affected, putting the progress of the lesson at risk, because according to Coral \& Lleixà (2014) the activities do not arouse much interest in the students or hinder the development of the motor aspects of the task.

Coral \& Lleixà (2014) also discuss that prioritizing or over-emphasizing linguistic aspects compromises task performance. Such tasks, focusing on linguistic aspects, slow down the motor dimension of the lesson.

Ramos \& Omenaca (2011) and Coral \& Lleixà (2014) point out that the second language can unintentionally become an alien element, which negatively affects students' interest and motivation for physical education classes.

And to solve this dilemma, Coral \& Lleixà (2014) used, in an adapted way, Gibbons' (2009) quadrants, which relate cognitive-communicative challenges and linguistic aids in the teaching environment. The figure below represents the feeling the students would get from the activities.

Figure 1. Representation of student motivation.

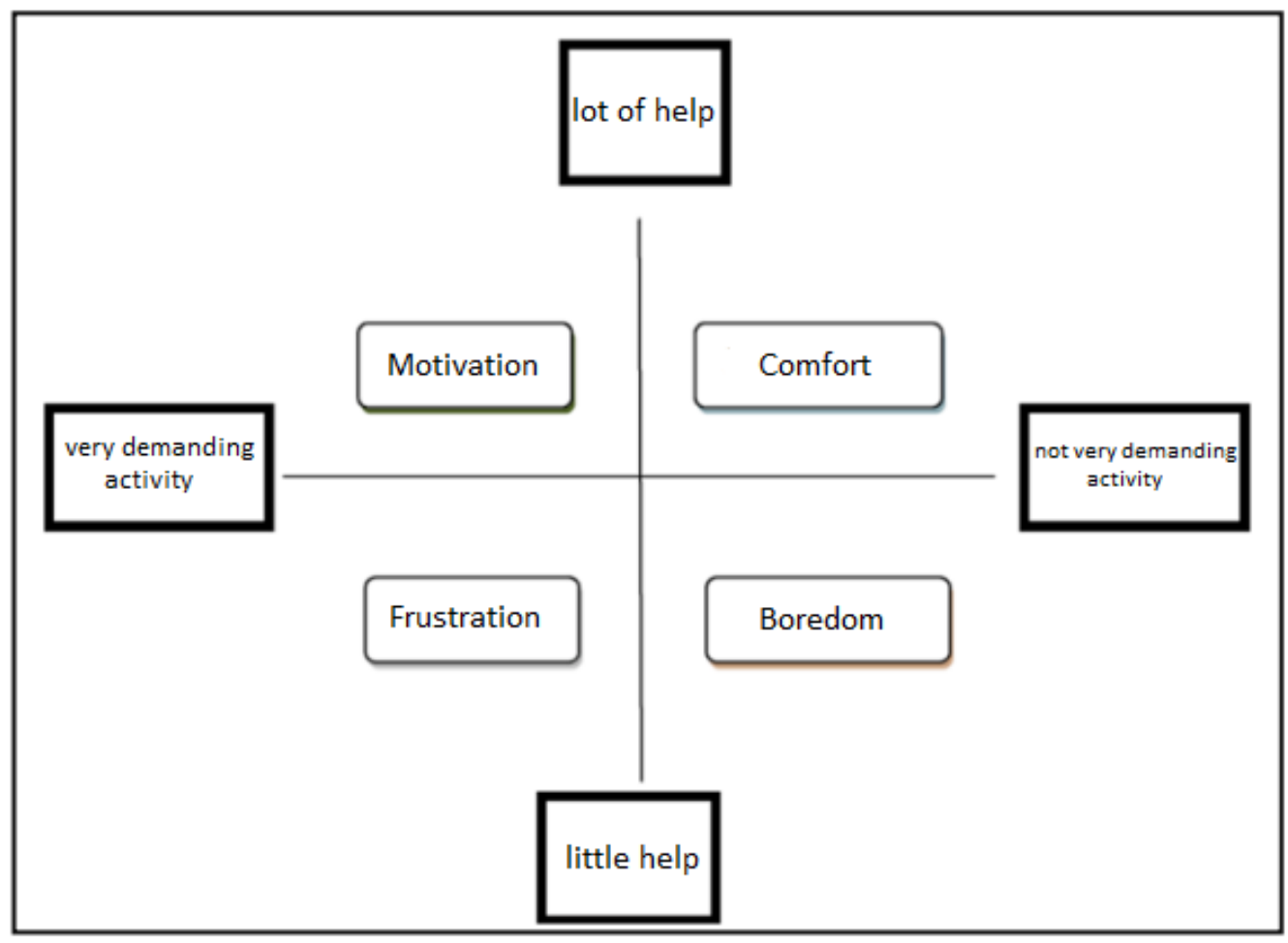

Source: Coral and Lleixà (our translation) (2014, p. 1461). 
Coral \& Lleixà (2014) argue that to solve this dilemma it is always necessary to focus on combining the very demanding activity with a lot of help, for understanding, thus motivating the student for lessons.

Ramos \& Omenaca (2011) mention that feelings and emotions are of diverse nature, and it is necessary to be aware that motor activities converge in joy, affection, satisfaction, sensitivity, or empathy, but also, frustration, fear, confusion, or resentment.

Ramos \& Omenaca (2011) conclude it is necessary to deepen the recognition of the affective aspect of physical education and the expression of emotions and feelings, as the class is done through a vehicle of communication that is unusual in the lives of the students, it is necessary to support them in the form of vocabulary, structures, and language strategies that allow them to express their emotions in this new language, avoiding, whenever possible, the negative emotions mentioned above.

\section{Dilemma 2: balanced activities and unbalanced activities}

Coral \& Lleixà (2014) cite that the goals of physical education, within the CLIL methodology, are balanced, when motor content, language, cognitive development, and social and/or societal development have a similar degree of demand during lessons.

In the text, Coral \& Lleixà (2014) bring the resolution of the dilemma focused on the CLIL methodology, citing, for example the four Cs (content, cognition, communication, culture), during its resolution in the article. As this article seeks to present a broader perspective of bilingual physical education, this dilemma will not be explored within the CLIL perspective, but rather adapted to a broader conception.

Dilemma 2 can be adapted as the realization of all demands, guidelines, and goals of normal physical education within bilingual physical education. With such definition, it is possible to apply dilemma 2 in other teaching realities, such as the reality of Brazilian bilingual physical education, which has, as mentioned above, to contemplate all content and guidelines present in the BNCC.

However, for such a dilemma to be solved, it is necessary that the teacher always be attentive in his planning to contemplate all the demands of bilingual physical education within the teaching context.

Mateu (2013) cites that most bilingual physical education teachers do not invest adequate time for this task, due to numerous factors. Thus, there may be an omission of content/activities.

The two dilemmas present in a concentrated way the difficulties of the bilingual physical education teacher, but they are still separated. Therefore, in the following section we seek to present based on the article of Coral \& Lleixà (2014) and with our personal experience within bilingual physical education, the three pillars that support bilingual physical education, and the most common mistakes that can generate an imbalance in this relationship.

\section{THE THREE PILLARS OF BILINGUAL PHYSICAL EDUCATION}

The concept "three pillars" was created to better illustrate the imbalances that can happen within bilingual physical education classes in an integral way, with each pillar addressing a vital aspect of bilingual physical education.

The first pillar is physical education, covering all activities, goals, and directions of physical education, and such activities, goals, and directions will vary according to the place where the teacher teaches. The second pillar is the process of acquiring a new language, and the third pillar is the optimization of class time.

Obviously, all subjects need time optimization for better utilization, however, the third pillar is present to warn teachers about the lost activity time and for a better visualization of the ideal bilingual physical education. 
Therefore, the ideal bilingual physical education class is when the teacher can achieve a balance of the demands of the three pillars. However, there are three distinct imbalances that occur between these three pillars that will be explained below.

\section{Over-simplification of the language acquisition process}

This imbalance happens when the teacher focuses on the 1st pillar (physical education) and the 3 rd pillar (time optimization), but not on the 2 nd pillar (the process of acquiring a new language). Where the teacher during his classes uses mostly the first language for communication with the students, eventually using the second language, with specific punctual phrases or loose words.

The most common justification for such action is related to trying to bring the activity time of bilingual physical education closer to a normal physical education class, which in our understanding, mischaracterizes the bilingual physical education class, turning it into, at best, a physical education class with words in English, which contributes nothing to the process of acquiring a new language, besides the eventual acquisition of common vocabulary of the subject.

In other cases, this happens because the teacher does not have an adequate command of the language that needs to be worked on, further limiting the use of the second language, or in extreme cases abandons all bilingual aspects.

\section{Imbalance in the language acquisition process}

This imbalance occurs when the teacher focuses on the 2 nd pillar (acquisition process of a new language) and the 3rd pillar (time optimization), but not on the 1st pillar (physical education). This situation happens when the teacher has an exaggerated focus on the process of acquiring a new language, causing the objectives, activities, and directions of physical education not to be contemplated by the lack of time, reducing the bilingual physical education class to a class of acquisition of a new language, with physical activities out of context of the objectives of physical education.

This situation can happen because of the teacher's own inexperience, where the teacher trying to contemplate the requirement of acquiring a new language can often take an excessive amount of time in his or her explanations, drastically reducing the time dedicated to physical education activities.

The situation can also happen due to an excessive focus on the motor part of physical education, where the teacher limits his classes to simple activities or activities that the students already know. The justification would be to facilitate communication and not "waste" class time, thus reducing bilingual physical education to a recreational class or a class that reproduces motor gestures.

\section{No optimization of class time}

This imbalance happens when the teacher has focus on the 1st pillar (physical education), on the 2nd pillar (new language acquisition process) but has no focus on the 3rd pillar (time optimization). In this situation, the teacher tries to contemplate all the activities and goals of physical education within the process of acquiring a new language, however, due to the lack of knowledge of specific strategies and methodologies of bilingual physical education, the teacher sees the total time of physical activity drastically reduced, because it takes too much time during his explanations and contextualizations.

Again, this situation can also be due to the teacher's lack of knowledge of the language selected for bilingual education. 


\section{CONCLUSION}

Bilingual physical education is a very complex subject, which unfortunately is often oversimplified, consequently devaluing the discipline, and causing confusion and anxiety for teachers who often do not understand the complexity of the demands they will face.

The subject in question presents several opportunities in the process of language acquisition, however, there is an inherent reduction in the speed of the class, mainly reducing the time of the activities.

There is also a constant search for balance between everything that encompasses physical education and the process of acquiring a new language. Where translation, as presented, can be a valuable tool. However, it cannot be used constantly, because it mischaracterizes bilingual physical education, and makes the student dependent on translation. Therefore, in a class where everything is translated, the student has no incentive to engage in the process of acquiring a new language.

Coral \& Lleixà (2014) provide an excellent analysis of the difficulties that teachers face seeking this balance in their classes, their analysis, however, has a focus on the CLIL methodology, which may alienate those who do not teach within the methodology.

The concept of the three pillars of bilingual physical education was coined based on Coral \& Lleixà (2014) and with our personal experience in the area, in which we sought to present all the demands of bilingual physical education in a comprehensive way, where the teacher could see a direct and objective representation of all aspects of bilingual physical education, where the errors (presented as imbalances) could be visualized and described, also in a direct way.

The three pillars represent all the elements that need to be considered for an ideal bilingual physical education class, 1st pillar the physical education itself, and all its guidelines and goals, whether they are presented by the CLIL methodology or the BNCC as in the case of Brazil, 2nd pillar the process of acquiring a new language, and 3rd pillar the optimization of class time to incorporate the process of acquiring a new language.

Bilingual physical education is a broad topic that needs to be constantly expanded, in which it is necessary that more people publish about the topic, so that bilingual physical education is not limited or misinterpreted.

Authors' Contributions: Muller, A.: conception and design, acquisition of data, analysis and interpretation of data, drafting the article, critical review of important intellectual content; Rodrigues Júnior, C. C.: conception and design, acquisition of data, analysis and interpretation of data, drafting the article, critical review of important intellectual content. The authors have read and approved the final version of the manuscript.

Ethics Approval: Not applicable.

Acknowledgments: Not applicable.

\section{REFERENCES}

Brasil (2018). Base Nacional Comum Curricular. Ministério da Educação.

Council, B. (2020). CLIL. Teaching English. Retrieved August 3, 2021, from https://www.teachingenglish.org.uk/article/clil

Camargo, F. C. D. S. (2012). Tradução e língua materna na aula de língua inglesa: o (s) discurso (s) dos professores. Dissertação (Mestrado em Linguística Aplicada). Universidade Estadual de Campinas, Instituto de Estudos da Linguagem, Campinas, SP, Brasil.

Chiva-Bartoll, Ó., Isidori, E., \& Fazio, A. (2015). Educación Física bilingüe y pedagogía crítica: una aplicación basada en el Judo. Retos: nuevas tendencias en educação física, deporte y recreación, 28, pp. 110-115.

Coral, J. (2012). Contribution of physical education in CLIL to english oracy. TRICLIL proceedings: Better CLIL: more opportunities in primary, secondary and higher education. Retrieved from: https://ddd.uab.cat/record/93319? In=ca 
Coral, J., \& Lleixà, T. (2014). O ensino da educação física mediante o enfoque educativo clil: a resolução dos dilemas profissionaiss surgidos durante um processo de pesquisa-ação. Movimento (ESEFID/UFRGS), 20(4), 1447-1472.

Gibbons, P. (2009). Challenging pedagogies: More than just good practice. Naldic Quarterly, 6(2), 4-14.

González, M. D. (2017). The use of translation in an integrated plurilingual approach to language learning: Teacher strategies and best practices. Journal of Spanish Language Teaching, 4(2), 124-135.

Griva, E., Semoglou, K., \& Geladari, A. (2010). Early foreign language learning: Implementation of a project in a gamebased context. Procedia-Social and Behavioral Sciences, 2(2), 3700-

Grosjean, F. (1997). The bilingual individual. . Interpreting, 2(1-2), 163-187.

Hita, F. J. M., \& Canto, E. G. (2017). Influencia del bilingüismo en el tiempo de compromiso motor en Educación Física. Retos: nuevas tendencias en educación física, deporte y recreación, 32, 178-182.

Liao, P. (2006). EFL learners' beliefs about and strategy use of translation in English learning. RELC Journal, 37(2), 191215.

Macaro, E. (2001). Analysing student teachers' codeswitching in foreign language classrooms: Theories and decision making. The Modern Language Journal, 85(4), 531-548.

Mateu, J. C. (2013). Physical education and English integrated learning: How school teachers can develop PE-in-CLIL programmes. Temps d'educació, 45, 41-61.

Ramos, F., \& Omenaca, J. V. R. (2011). La educación física en centros bilingües de primaria inglés-español: de las singularidades propias del área a la elaboración de propuestas didácticas prácticas con AIBLE. Revista española de lingüística aplicada, 24, 153-170.

Salvador-García, C., Chiva-Bartoll, O., \& Isidori, E. (2017). Aprender uma língua estrangeira através da educação física: uma revisão sistemática. Movimento 23(2), 647-660.

Sharma, K. (2006). Mother tongue use in English classroom. Journal of NELTA, 11(1-2), 80-87.

Spahiu, I. (2013). Using native language in ESL classroom. International Journal of English Language \& Translation Studies, 1(2), 243.

Stibbard, R. (1994). The use of translation in foreign language teaching. Perspectives: Studies in translatology, 2(1), 918.

Vermes, A. (2010). Translation in foreign language teaching: a brief overview of pros and cons. Eger Journal of English Studies, 10(1), 83-93.

Vieira, M. C. (2019). Escolas bilíngues se espalham pelo país, isso é bom - e custa caro. Veja. Retrieved April 26, 2020, from https://veja.abril.com.br/educacao/escolas-bilingues-se-espalham-pelo-pais-isso-e-bom-e-custa-caro/

Received: 19 May 2021 | Accepted: 1 August 2021 | Published: 24 August 2021 